\title{
Response of Neem Cake Rhizobium and Inorganic Fertilizer on Soil Health Growth and Yield of Green gram (Vigna radiata L.) var. Samrat
}

\author{
Rajesh and Arun Alfred David*
}

\author{
Department of Soil Science and Agricultural Chemistry, Sam Higginbottom University of \\ Agriculture, Technology and Sciences, Allahabad, 211007(U.P.), India \\ *Corresponding author
}

\begin{tabular}{|c|}
\hline Keywords \\
\hline $\begin{array}{l}\text { Soil nutrients, } \\
\text { Yield attributes, } \\
\text { N P\&K, Neem } \\
\text { cake, Rhizobium } \\
\text { and Green gram. }\end{array}$ \\
\hline Article Info \\
\hline $\begin{array}{l}\text { Accepted: } \\
\text { 14 June } 2017 \\
\text { Available Online: } \\
\text { 10 July } 2017\end{array}$ \\
\hline
\end{tabular}

\section{A B S T R A C T}

A study was conducted during kharif season 2016-17 to study the "Response of Neem cake Rhizobium and Inorganic Fertilizer on Soil Health Growth and Yield of Green gram (Vigna radiata L.) var. Samrat" on crop research farm department of Soil Science and Agricultural Chemistry, Naini Agricultural Institute, SHUATS, Allahabad. The design applied for statistical analysis was carried out with $3 \times 2 \times 2$ factorial randomized block design having three factors with three levels of NPK @ 0, 50, and $100 \%$ ha $^{-1}$, two level of Neem cake and Rhizobium @ 0,100\% respectively. The best treatment was $\mathrm{T}_{11}-\mathrm{I}_{2}+\mathrm{N}_{1}+\mathrm{R}_{1}$ (@ $100 \% \mathrm{~N} \mathrm{P} \mathrm{K} \mathrm{ha}{ }^{-1}+100 \%$ Neem cake and Rhizobium) that showed the significant increase on enrichment of soil fertility status. The textural classes' names are given to soils based upon the relative proportion of each of the three soil separates - sand, silt and clay. Sandy loam in which sand is $61.21 \%$, silt $25.36 \%$ and clay $13.46 \%$. The combination of N P K, Neem cake and Rhizobium was show resulted in a slight decrease in particle density $\left(2.33 \mathrm{Mgm}^{-3}\right)$, bulk density $\left(1.11 \mathrm{Mgm}^{-3}\right), \mathrm{pH} 6.97$ and EC $0.28 \mathrm{dSm}^{-1}$ in post-harvest soil. The maximum increased values were recorded of O.C $(0.74 \%)$, pore space $(59.58 \%)$, water holding capacity $(56.62 \%)$ and available macro nutrient as Nitrogen $\left(314.84 \mathrm{~kg} \mathrm{ha}^{-1}\right)$, Phosphorus $\left(33.45 \mathrm{~kg} \mathrm{ha}^{-1}\right)$ and Potassium $\left(181.05 \mathrm{~kg} \mathrm{ha}^{-1}\right)$ with treatment combination $\mathrm{T}_{11-}$ $\left[\mathrm{I}_{2}+\mathrm{N}_{1}+\mathrm{R}_{1}\right.$ (@100\% N P K ha ${ }^{-1}+100 \%$ Neem cake and Rhizobium]. The maximum cost benefit ratio was recorded 1:2.73 and maximum net return Rs. 58651 per hectare and maximum yield $13.58 \mathrm{q} \mathrm{ha}^{-1}$ in treatment combination $\mathrm{T}_{11}-\left[\mathrm{I}_{2}+\mathrm{N}_{1}+\mathrm{R}_{1} @ 100 \% \mathrm{~N} \mathrm{P} \mathrm{K} \mathrm{ha}{ }^{-1}+\right.$ $100 \%$ Neem cake and Rhizobium].

\section{Introduction}

In India, production of pulses is around 13.515 million tonns during the last decade, while annual domestic demand is $18-19$ million tons. The yield of pulses has remained virtually stagnant for the last 40 year (539 $\mathrm{kg} / \mathrm{ha}$ in 1961 to $544 \mathrm{~kg} / \mathrm{ha}$ in 2001 to 651 $\mathrm{kg} / \mathrm{ha}$ in 2013-14).

India is short of supply by 2 to 3 million tonns annually. (Agropedia, 2014-15). Green gram
[Vigna radiata $L$.] $(2 \mathrm{n}=2 \mathrm{x}=22)$ is third important pulse after chickpea and Pigeon pea. It is a self-pollinated crop and is an important grain legume of the tropical area. Greengram is also called mung, moong, mungo, greengram, goldengram, chicksaw pea and Oregon pea. It belongs to the Family Fabaceae and sub Family Papilionaceae. The center of origin is India (Karpechenko, 1925). Majority of Indian population is vegetarian, 
pulses are cheap and best source of protein for Indian diet. It contains 20-25 percent protein, which is more than two times of cereals. India is importing about 3 million tonnes and the future demand of pulses by 2017 will be 28.0 million tonnes (Anonymous, (2011).

In India, it is cultivated in Maharashtra, Andhra Pradesh, Rajasthan, Orissa, Karnataka and Uttar Pradesh. Green gram contributes $18.07 \%$ of total pulses area and $11.48 \%$ of total pulses production in India.

Area, production and productivity of greengram in India are 34.4 lakh ha, 14 lakh tonnes and $406.98 \mathrm{~kg} / \mathrm{ha}$ respectively (Iipr.res.in, 2014-15).

Green gram is an excellent source of protein. It is rich in lysine and deficient in methionine and legume, which is free from antinutritional factor. The range for protein content is fairly wide (20- $24 \%$ per $100 \mathrm{~g}$ of dry grain).

Temperature of $28^{\circ} \mathrm{C}$ to $33^{\circ} \mathrm{C}$ is optimum for seed germination and plant growth. Green gram plants are erect with few branches carrying pods borne is cluster and near the top of the pant. Pods contain 8- 15 green seeds (Prasad, 2009).

The green gram (Vigna radiata L. Wilczek) is one of the important pulse crop because of its adaptation to short growth duration, low water requirement, soil fertility and is favoured for consumption due to its easy digestibility and low production of flatulence (Shil and Bandopadhya, 2007).

\section{Nitrogen}

Green gram is capable of fixing atmospheric nitrogen, it responds to small quantity of nitrogenous fertilizers applied as starter dose. Application of $15-20 \mathrm{Kg} \mathrm{Nha}{ }^{-1}$ has been found optimum to get better response.
Application of higher dose of nitrogen may reduce nodule number and nodule growth and thus adversely affect the nitrogen fixation capacity.

\section{Phosphorus}

Phosphorus plays a vital role in photosynthesis, respiration, energy storage, cell elongation and improves the quality of crops. Deficient plants may have thin, erect and spindly stems and leaves turn into bluishgreen colour. Phosphorus is an essential constituent of majority of enzymes, which are of great importance in the transformation of energy, in carbohydrate metabolism, in fat metabolism and also in respiration of plants. It enhances the activity of Rhizobium and increased the formation of root nodules. Thus, it helps in fixing more of atmosphere nitrogen in root nodules (Rajveer et al., 2016).

\section{Neem cake}

Neem cake is a potential source of organic manure. Neem has demonstrated considerable potential as a fertilizer. Our Neem cake also reduce alkalinity in soil, as it produce organic acid on decomposition, being totally natural, the Neem cake we offer hence ensure fertility of the soil, it also improve the organic matter contain of the soil, helping improvement in soil texture, water holding capacity, soil aeration for batter root development.

The addition of Neem cake also positively affected the available soil organic carbon, N P $\mathrm{K}$ and $\mathrm{Mn}$ content of soil resulting better growth and grain yield of mung bean (Vigna radiata L.) besides suppressing soil borne pathogens (Murugan, 2011). The composition of Neem cake is $5.2 \% \mathrm{~N}, 1.0 \% \mathrm{P}, 1.4 \% \mathrm{~K}$. Neem cake act as a nitrogen inhibitor means reduce the nitrification. It supplies the available nitrogen for a long time in the soil (Katyayan, 2012). 


\section{Rhizobium}

The use of biofertilizers are more eco-friendly in nature. They can play a significant role in fixing atmospheric nitrogen; biofertilizers enrich soil fertility and improves soil fertility. Of these biofertilizers, Rhizobium inoculants specific for different leguminous crop is the most important in India. The largest contribution of biological nitrogen fixation to agriculture is derived from the symbiosis between legumes and Rhizobium species (Meena et al., 2016).

\section{Materials and Methods}

A field experiment was conducted on research farm of department of Soil Science and Agricultural Chemistry SHUATS Allahabad, (U.P.) India. The soil of experimental area falls in order Inception and the experimental field is Alluvial in nature. The design applied for statistical analysis was carried out with $3 \times 2 \times 2$ factorial randomized block design having three factors with three levels of N P $\mathrm{K} @ 0$, 50, and $100 \% \mathrm{ha}^{-1}$, two levels of Neem cake@ @ and 100\% $\mathrm{ha}^{-1}$ and two level of Rhizobium @ 0 and 100\% ha ${ }^{-1}$ respectively (Table 1).

\section{Experimental site}

The experiment was conducted at research Farm of Soil Science at Sam Higginbottom University of Agriculture Technology and Sciences, Allahabad, the area is situated on the south of Allahabad on the right side of the river Yamuna on the South of Rewa Road at a distance of about $6 \mathrm{Km}$ from Allahabad city. It is situated at $25^{\circ} 24^{\prime} 23^{\prime \prime} \mathrm{N}$ latitude, $81^{\circ} 50^{\prime} 38^{\prime \prime}$ E longitude and at the altitude of 98 meter above the sea level (Table 2).

\section{Climate condition in the experimental area}

The area of Allahabad district comes under subtropical belt in the South east of Uttar
Pradesh, which experience extremely hot summer and fairly cold winter. The maximum temperature of the location reaches up to $46^{\circ} \mathrm{C}$ $-48^{\circ} \mathrm{C}$ and seldom falls as low as $4^{\circ} \mathrm{C}-5^{\circ} \mathrm{C}$. The relative humidity ranged between 20 to 94 percent. The average rainfall in this area is around $1100 \mathrm{~mm}$ annually.

The source of nitrogen, phosphorus, neem cake and biofertilizers are as urea, SSP, neem cake, Rhizobium culture respectively. The Neem cake applied to some day of before sowing because well decomposed and not direct contact to seed. Basal dose of fertilizer was applied in respective plots according to treatment allocation unifurrows opened by about $5 \mathrm{~cm}$. depth before sowing seeds in soil at the same time sowing of seeds was sown on well prepared beds in shallow furrows, at the depth of $5 \mathrm{~cm}$, row to row distance was maintained at $30 \mathrm{~cm}$ and plant to plant distance was $10 \mathrm{~cm}$, during the course of experiment, observations were recorded as mean values of the data.

\section{Results and Discussion}

Table 3 shows the interaction effects of $\mathrm{N} \mathrm{P}$ $\mathrm{K}$, Neem cake and Rhizobium are generally influenced physical and chemical properties of post-harvest soil.

\section{Physical properties}

The interaction effects of N P K, Neem cake and Rhizobium on bulk density $\left(\mathrm{Mg} \mathrm{m}^{-3}\right)$, particle density $\left(\mathrm{Mg} \mathrm{m}^{-3}\right)$, \% Pore space and Water holding capacity was significant. The maximum bulk density, particle density of after crop harvest soil was recorded as 1.40 $\mathrm{Mg} \mathrm{m} \mathrm{m}^{-3}, 2.51 \mathrm{Mg} \mathrm{m}^{-3}$ respectively in $\mathrm{T}_{0}$ $\left(\mathrm{I}_{0}+\mathrm{N}_{0}+\mathrm{R}_{0}\right) @ 0 \% \mathrm{~N} \mathrm{P} \mathrm{K} \mathrm{ha}{ }^{-1}+@ 0 \%$ Neem cake@ ha ${ }^{-1}+@ 0 \%$ Rhizobium ha ${ }^{-1}$ and minimum bulk density $1.11 \mathrm{Mg} \mathrm{m}^{-3}$, particle density $2.33 \mathrm{Mg} \mathrm{m}^{-1}$ respectively in @ $\mathrm{T}_{11^{-}}$ $\left(\mathrm{I}_{2}+\mathrm{N}_{1}+\mathrm{R}_{1}\right) @ 100 \% \mathrm{~N} \mathrm{P} \mathrm{K} \mathrm{ha}{ }^{-1}+@ 100 \%$ Neem cake + 100\%@Rhizobium. The 
highest Pore space and Water holding capacity of soil was recorded 56.62 in @ $\mathrm{T}_{11^{-}}$ $\left(\mathrm{I}_{2}+\mathrm{N}_{1}+\mathrm{R}_{1}\right) @ 100 \%$ N P K ha ${ }^{-1}+@$ Neem cake $0.5 \mathrm{t} \mathrm{ha}^{-1}+$ Rhizobium @ $20 \mathrm{~g} / \mathrm{Kg}$ seed.

\section{Chemical properties of post soil}

During the course of study, it was observed that the highest $\mathrm{pH}$ was recorded in $7.41 \mathrm{~T}_{0}$ $\left(\mathrm{I}_{0}+\mathrm{N}_{0}+\mathrm{R}_{0}\right) @ 0 \% \mathrm{~N} \mathrm{P} \mathrm{K} \mathrm{ha}{ }^{-1}+@ 0 \%$ Neem cake ha ${ }^{-1}+@$ Rhizobium ha ${ }^{-1}$ and the lowest of 6.97 was recorded with the application of treatment $\mathrm{T}_{11}\left(\mathrm{I}_{2}+\mathrm{N}_{1}+\mathrm{R}_{1}\right) @ 100 \%$ N P K ha ${ }^{-1}$ $+@ 100 \%$ Neem cake ha ${ }^{-1}+@ 100 \%$ Rhizobium. If we compare the $\mathrm{pH}$ of pre sowing soil sample which was 7.44 with that of after crop harvest soil, there was decrease in $\mathrm{pH}$ after crop harvest. Increasing dose of $\mathrm{N}$ $\mathrm{P} \mathrm{K}$ and Neem cake lightly decrease $\mathrm{pH}$ of the post-harvest soil. The decrease in $\mathrm{pH}$ might be due to higher growth of crops as respiration is more. Respiration evolves carbon dioxide and reacts with water to form carbonic acid in soil.

Organic carbon (\%), available nitrogen, phosphorus and potassium $\left(\mathrm{kg} \mathrm{ha}^{-1}\right)$ were increased in soil after crop harvests. The chemical properties were significantly affected by different treatment combination of N P K, Neem cake and Rhizobium.

Table.1 Treatment combination of green gram

\begin{tabular}{|c|c|c|}
\hline Treatment & Description & Symbol \\
\hline $\mathrm{T}_{0}$ & @ $\mathrm{N}_{0} \mathrm{P}_{0} \mathrm{~K}_{0} \mathrm{Kg} \mathrm{ha}^{-1}+$ Neem cake @ $0 \mathrm{t} \mathrm{ha}^{-1}+$ Rhizobium @0 g/ Kg seed & $\mathrm{I}_{0} \mathrm{~N}_{0} \mathrm{R}_{0}$ \\
\hline $\mathrm{T}_{1}$ & @ $\mathrm{N}_{0} \mathrm{P}_{0} \mathrm{~K}_{0} \mathrm{Kg} \mathrm{ha}^{-1}+$ Neem cake @ 0t ha ${ }^{-1}+$ Rhizobium @ $20 \mathrm{~g} / \mathrm{Kg}$ seed & $\mathrm{I}_{0} \mathrm{~N}_{0} \mathrm{R}_{1}$ \\
\hline $\mathrm{T}_{2}$ & $@ \mathrm{~N}_{0} \mathrm{P}_{0} \mathrm{~K}_{0} \mathrm{Kg} \mathrm{ha}^{-1}+$ Neem cake @ $0.5 \mathrm{tha}^{-1}+$ Rhizobium @0 g/ Kg seed & $\mathrm{I}_{0} \mathrm{~N}_{1} \mathrm{R}_{0}$ \\
\hline $\mathrm{T}_{3}$ & $@ \mathrm{~N}_{0} \mathrm{P}_{0} \mathrm{~K}_{0} \mathrm{Kg} \mathrm{ha}^{-1}+$ Neem cake @ $0.5 \mathrm{t} \mathrm{ha}^{-1}+$ Rhizobium @ $20 \mathrm{~g} / \mathrm{Kg}$ seed & $\mathrm{I}_{0} \mathrm{~N}_{1} \mathrm{R}_{1}$ \\
\hline $\mathrm{T}_{4}$ & $@ \mathrm{~N}_{10} \mathrm{P}_{20} \mathrm{~K}_{0} \mathrm{Kg} \mathrm{ha}^{-1}+$ Neem cake @ $0 \mathrm{tha}^{-1}+$ Rhizobium @0 g/ Kg seed & $\mathrm{I}_{1} \mathrm{~N}_{0} \mathrm{R}_{0}$ \\
\hline $\mathrm{T}_{5}$ & @ $\mathrm{N}_{10} \mathrm{P}_{20} \mathrm{~K}_{0} \mathrm{Kg} \mathrm{ha}^{-1}+$ Neem cake @ $0 \mathrm{tha}^{-1}+$ Rhizobium @ $20 \mathrm{~g} / \mathrm{Kg}$ seed & $\mathrm{I}_{1} \mathrm{~N}_{0} \mathrm{R}_{1}$ \\
\hline $\mathrm{T}_{6}$ & $@ \mathrm{~N}_{10} \mathrm{P}_{20} \mathrm{~K}_{0} \mathrm{Kg} \mathrm{ha}^{-1}+$ Neem cake @ $0.5 \mathrm{tha}^{-1}+$ Rhizobium @0 g/ Kg seed & $\mathrm{I}_{1} \mathrm{~N}_{1} \mathrm{R}_{0}$ \\
\hline $\mathrm{T}_{7}$ & $@ \mathrm{~N}_{10} \mathrm{P}_{20} \mathrm{~K}_{0} \mathrm{Kg} \mathrm{ha}^{-1}+$ Neem cake @ $0.5 \mathrm{tha}^{-1}+$ Rhizobium @ $20 \mathrm{~g} / \mathrm{Kg}$ seed & $\mathrm{I}_{1} \mathrm{~N}_{1} \mathrm{R}_{1}$ \\
\hline $\mathrm{T}_{8}$ & $@ \mathrm{~N}_{20} \mathrm{P}_{40} \mathrm{~K}_{0} \mathrm{Kg} \mathrm{ha}^{-1}+$ Neem cake @ $0 \mathrm{tha}^{-1}+$ Rhizobium @0 g/ Kg seed & $\mathrm{I}_{2} \mathrm{~N}_{0} \mathrm{R}_{0}$ \\
\hline $\mathrm{T}_{9}$ & @ $\mathrm{N}_{20} \mathrm{P}_{40} \mathrm{~K}_{0} \mathrm{Kg} \mathrm{ha}^{-1}+$ Neem cake @ $0 \mathrm{tha}^{-1}+$ Rhizobium @ $20 \mathrm{~g} / \mathrm{Kg}$ seed & $\mathrm{I}_{2} \mathrm{~N}_{0} \mathrm{R}_{1}$ \\
\hline $\mathrm{T}_{10}$ & $@ \mathrm{~N}_{20} \mathrm{P}_{40} \mathrm{~K}_{0} \mathrm{Kg} \mathrm{ha}^{-1}+$ Neem cake @ $0.5 \mathrm{tha}^{-1}+$ Rhizobium @ $0 \mathrm{~g} / \mathrm{Kg}$ seed & $\mathrm{I}_{2} \mathrm{~N}_{1} \mathrm{R}_{0}$ \\
\hline $\mathrm{T}_{11}$ & $@ \mathrm{~N}_{20} \mathrm{P}_{40} \mathrm{~K}_{0} \mathrm{Kg} \mathrm{ha}^{-1}+$ Neem cake @ $0.5 \mathrm{tha}^{-1}+$ Rhizobium @ $20 \mathrm{~g} / \mathrm{Kg}$ seed & $\mathrm{I}_{2} \mathrm{~N}_{1} \mathrm{R}_{1}$ \\
\hline
\end{tabular}

Table.2 Mechanical analysis of pre experimental soil

\begin{tabular}{lll}
\hline Particulars & Method employed & \\
\hline Sand $(\%)$ & (Bouyoucos,1927) & 61.21 \\
Silt $(\%)$ & & 25.36 \\
Clay (\%) & & 13.43 \\
Textural class & Sandy loam \\
Soil Colour & & \\
Dry Soil & & Pale brown \\
Wet Soil & (Muthuaval,1992) & Olive brown \\
Bulk density $\left(\mathrm{Mg} \mathrm{m}^{-3}\right)$ & (Muthuaval, 1992) & 1.32 \\
Particle density $\left(\mathrm{Mg} \mathrm{m}^{-3}\right)$ & (Black, 1965) & 2.48 \\
Pore Space $(\%)$ & & 46.42 \\
\hline
\end{tabular}


Table.3 Chemical analysis of pre experimental soil

\begin{tabular}{lll}
\hline Parameters & Method employed & \\
\hline Soil $\mathrm{pH}(1: 2)$ & (Jackson,1958) & 7.33 \\
Soil EC $\left(\mathrm{dS} \mathrm{m}^{-1}\right)$ & (Wilcox, 1950) & 0.30 \\
Organic Carbon $(\%)$ & (Walleye and Black, 1947) & 0.55 \\
Available Nitrogen $\left(\mathrm{Kg} \mathrm{ha}^{-1}\right)$ & (Sabbath and Asija, 1956) & 287.08 \\
Available Phosphorus $\left(\mathrm{Kg} \mathrm{ha}^{-1}\right)$ & (Olsen et al., 1950) & 23.11 \\
Available Potassium $\left(\mathrm{Kg} \mathrm{ha}^{-1}\right)$ & (Toth and Prince, 1949) & 163.60 \\
\hline
\end{tabular}

Table.4 Effect of different levels of N P K Neem cake and Rhizobium on post-harvest soil properties of Green gram

\begin{tabular}{|c|c|c|c|c|c|c|c|c|c|}
\hline $\begin{array}{c}\text { Treatment } \\
\text { combination }\end{array}$ & $\begin{array}{c}\text { Bd } \\
\left(\mathrm{Mg} \mathrm{m}^{-3}\right)\end{array}$ & $\begin{array}{c}\text { Pd } \\
\left(\mathrm{Mg} \mathrm{m}^{-3}\right)\end{array}$ & $\begin{array}{c}\text { WHC } \\
(\%)\end{array}$ & $\begin{array}{c}\mathbf{p H} \\
(1: 2 \mathrm{w} / \mathrm{v})\end{array}$ & $\begin{array}{c}\mathbf{E c} \\
\left(\mathbf{d S m}^{-1}\right)\end{array}$ & $\begin{array}{l}\text { O.C } \\
(\%)\end{array}$ & $\begin{array}{c}\mathrm{N} \\
\left(\mathrm{kg} \mathrm{ha}^{-1}\right)\end{array}$ & $\begin{array}{c}\mathrm{P}_{2} \mathrm{O}_{5} \\
\left(\mathrm{~kg} \mathrm{ha}^{-1}\right)\end{array}$ & $\begin{array}{c}\mathrm{K}_{2} \mathrm{O} \\
\left(\mathrm{kg} \mathrm{ha}^{-1}\right)\end{array}$ \\
\hline$\left(\mathrm{I}_{0}+\mathrm{N}_{0}+\mathrm{R}_{0}\right)$ & 1.40 & 2.51 & 48.13 & 7.41 & 0.33 & 0.54 & 287.13 & 23.35 & 168.85 \\
\hline$\left(\mathrm{I}_{0}+\mathrm{N}_{0}+\mathrm{R}_{1}\right)$ & 1.33 & 2.47 & 50.89 & 7.29 & 0.32 & 0.56 & 290.21 & 24.53 & 169.65 \\
\hline$\left(\mathrm{I}_{0}+\mathrm{N}_{1}+\mathrm{R}_{0}\right)$ & 1.31 & 2.46 & 51.33 & 7.21 & 0.31 & 0.59 & 289.26 & 25.17 & 174.47 \\
\hline$\left(\mathrm{I}_{0}+\mathrm{N}_{1}+\mathrm{R}_{1}\right)$ & 1.23 & 2.41 & 53.47 & 7.13 & 0.29 & 0.63 & 298.50 & 25.49 & 175.55 \\
\hline$\left(\mathrm{I}_{1}+\mathrm{N}_{0}+\mathrm{R}_{0}\right)$ & 1.35 & 2.47 & 51.22 & 7.27 & 0.32 & 0.58 & 295.51 & 26.19 & 170.24 \\
\hline$\left(\mathrm{I}_{\mathrm{I}}+\mathrm{N}_{0}+\mathrm{R}_{1}\right)$ & 1.29 & 2.45 & 52.85 & 7.23 & 0.31 & 0.60 & 303.61 & 27.20 & 173.51 \\
\hline$\left(\mathrm{I}_{1}+\mathrm{N}_{1}+\mathrm{R}_{0}\right)$ & 1.25 & 2.43 & 54.38 & 7.17 & 0.30 & 0.63 & 302.71 & 27.36 & 176.45 \\
\hline$\left(\mathrm{I}_{1}+\mathrm{N}_{1}+\mathrm{R}_{1}\right)$ & 1.17 & 2.38 & 56.28 & 7.03 & 0.29 & 0.70 & 307.07 & 28.25 & 176.42 \\
\hline$\left(\mathrm{I}_{2}+\mathrm{N}_{0}+\mathrm{R}_{0}\right)$ & 1.38 & 2.50 & 53.25 & 7.22 & 0.31 & 0.61 & 312.24 & 30.51 & 173.74 \\
\hline$\left(\mathrm{I}_{2}+\mathrm{N}_{0}+\mathrm{R}_{1}\right)$ & 1.19 & 2.40 & 56.11 & 7.08 & 0.30 & 0.68 & 313.87 & 31.54 & 175.51 \\
\hline$\left(\mathrm{I}_{2}+\mathrm{N}_{1}+\mathrm{R}_{0}\right)$ & 1.15 & 2.36 & 56.45 & 7.02 & 0.29 & 0.71 & 314.07 & 32.48 & 179.05 \\
\hline$\left(\mathrm{I}_{2}+\mathrm{N}_{1}+\mathrm{R}_{1}\right)$ & 1.11 & 2.33 & 56.62 & 6.97 & 0.28 & 0.74 & 314.84 & 33.45 & 181.05 \\
\hline F- test & $\mathrm{S}$ & $S$ & $S$ & NS & NS & $\mathrm{S}$ & $\mathrm{S}$ & $\mathrm{S}$ & NS \\
\hline S. Me $( \pm)$ & 0.008 & 0.010 & 0.04 & 0.11 & 0.032 & 0.012 & 0.81 & 0.05 & 224.37 \\
\hline C. D. at 5\% & 0.017 & 0.019 & 0.07 & 0.22 & 0.065 & 0.024 & 1.65 & 0.09 & 455.93 \\
\hline
\end{tabular}

Fig.1 Effect of different levels of N P K Neem cake and Rhizobium on Bd $\left(\mathrm{Mg} \mathrm{m}^{-3}\right)$ and $\mathrm{Pd}\left(\mathrm{Mg} \mathrm{m}^{-3}\right)$ post-harvest soil properties of Green gram

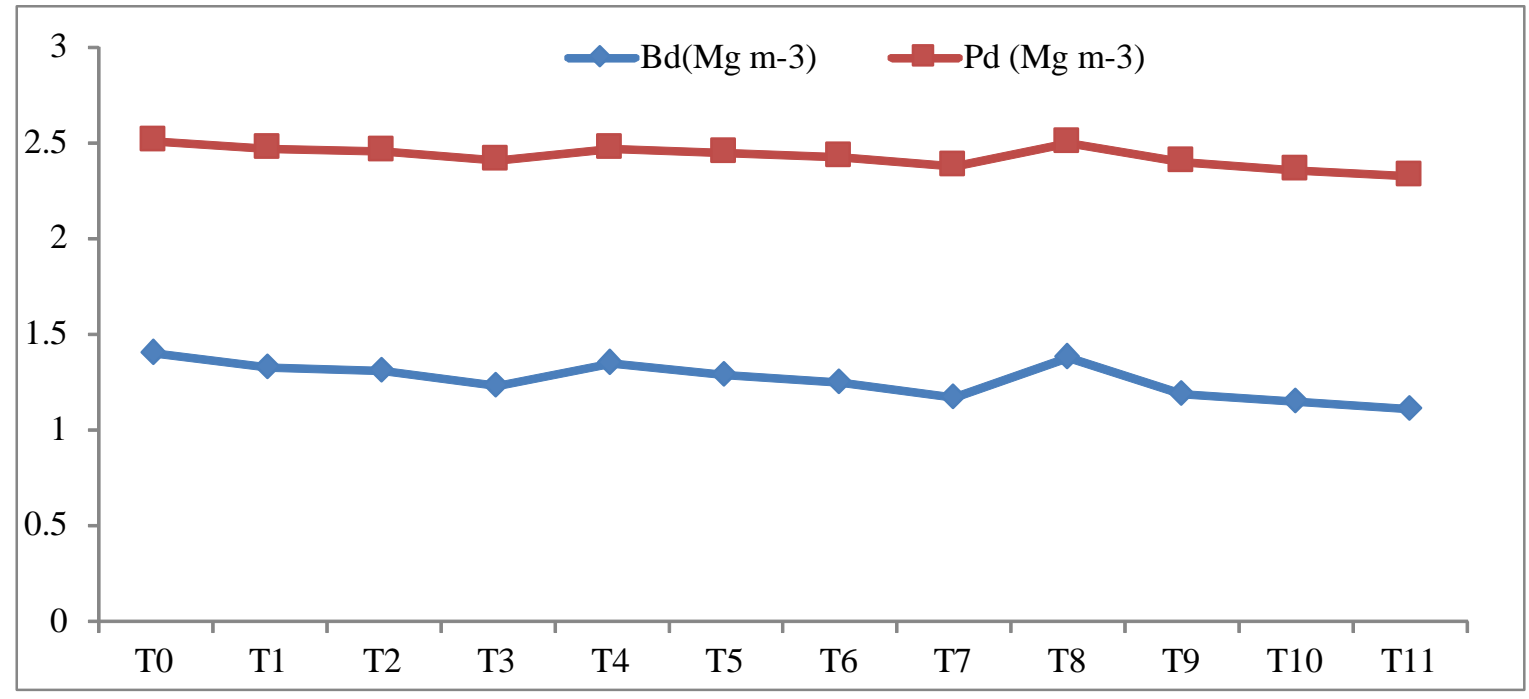


Fig.2 Effect of different levels of N P K Neem cake and Rhizobium on Post-harvest soil properties of Green gram

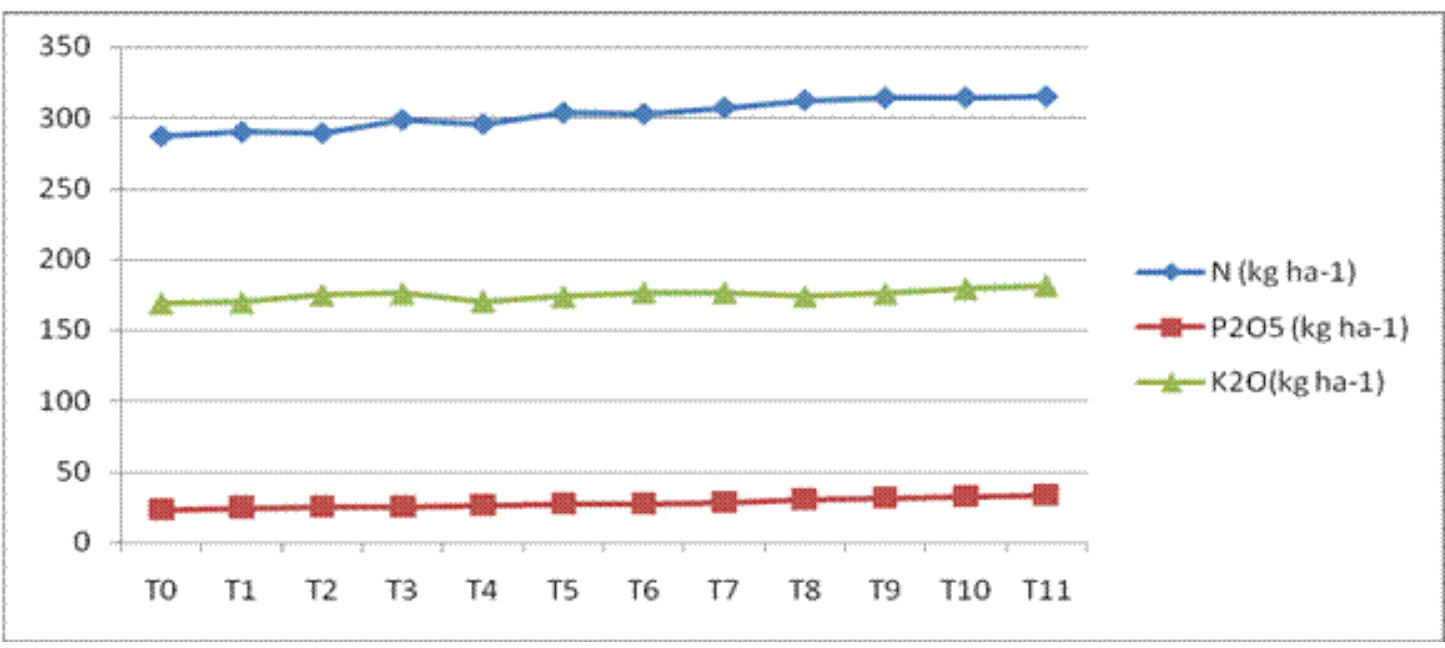

The effect of $\mathrm{N} \mathrm{P} \mathrm{K} \mathrm{fertilizer} \mathrm{on} \mathrm{organic}$ carbon (\%), available nitrogen, phosphorus, potassium $\left(\mathrm{kg} \mathrm{ha}^{-1}\right)$, electric conductivity $(\mathrm{dS}$ $\mathrm{m}^{-1}$ ) is significant. The maximum chemical properties of after crop harvest soil was recorded electric conductivity $\left(\mathrm{dS} \mathrm{m}^{-1}\right)$, organic carbon (\%), available nitrogen, phosphorus, potassium $\left(\mathrm{kg} \mathrm{ha}^{-1}\right) 0.330,0.74$, 314.84, 33.45, 181. respectively available Potassium $\left(\mathrm{kg} \mathrm{ha}^{-1}\right)$, Electric conductivity (ds $\mathrm{m}^{-1}$ ) and $\mathrm{pH}$ was found non-significant and Organic carbon (\%), Nitrogen $\left(\mathrm{kg} \mathrm{ha}{ }^{-1}\right)$, Potassium $\left(\mathrm{kg} \mathrm{ha}^{-1}\right)$ and Phosphorus $\left(\mathrm{kg} \mathrm{ha}^{-1}\right)$ found to be significant.

It was concluded from trial that the various level of N P K + Neem cake and Rhizobium used from in the experiment, the treatment combination $\mathrm{T}_{11}\left(\mathrm{I}_{2}+\mathrm{N}_{2}+\mathrm{R}_{1}\right) @ 100 \% \mathrm{~N}$ P K $\mathrm{ha}^{-1}+@ 100 \%$ Neem cake $0.5 \mathrm{t} \mathrm{ha}^{-1}+@$ $100 \%$ Rhizobium $20 \mathrm{~g} / \mathrm{Kg}$ seed was found to be the best treatment gave highest benefit of ₹ 58651with highest cost benefit ratio 1:2.73 for Green gram it could be recommended for profitable production of Green gram (Vigna radiata L.) var. Samrat, it improve soil physical and chemical properties. Integrated nutrient management is better for soil health and Green gram production (Table 4; Figs 1 and 3 ).

\section{Acknowledgement}

The author are thankful to the Hun' ble Vice Chancellor, HOD, Advisor and non-Teaching staff Department of Soil Science and Agricultural Chemistry, Sam Higginbottom University of Agriculture, Technology And Science Allahabad, U. P., for providing all necessary facilities, clarify studies.

\section{References}

Ahmed, Z. I., Anjum, M. S. and Raff, C. A. (2006) effect of Rhizobium Inoculation on Growth and Nodule Formation of Green gram. International Journal of Agriculture \&Biology.2:235-237

Agropedia, (2014-15)

Anonymous (2011). Agriculture Statistics at a Glance. Directorate of Economics and Statistics, New Delhi. The hydrometer as a new method for the mechanical analysis of soils. Soil Sci. 23: 393-395.

Anonymous (2009) Economic survey, Ministry of Finance, Government of India.

Black, C.A. (1965) Methods of soil analysis. Vol. I. Am. Soc. Agron. Madison, Wisconsin, U.S.A.

Brady, N.C. and Weil, R.R. (1996) the nature and properties of soils (11th Ed.). Prentice Hall, New York. 
Buoyoucos, G.J. (1952) A recalibration of the hydrometer method for making mechanical analysis of soil, 43, 434.

Eifediyi, E.K., Mohammed, K.O., Remison, S.U. (2015) effects of neem (Azadirachta indica L.) seed cake on the growth and yield of okra (Abelmoschus esculentus (L.) Moench) poljoprivreda21: (1) 46-52.

Fisher, R. A. (1950) Technique of Analysis of Variance.Handbook of Agricultural Statistics B-29- 110.

Hussain, A., Ali, A. and Ijaz, N. R. (2012) Effect of Phosphorus With and Without Rhizobium Inoculation on Nitrogen and Phosphorus Concentration and Uptake by Mungbean (Vigna radiata L.). J. Agric. Res., 2012, 50(1).

(Iipr.res.in, 2014-15) ICAR-Indian Institute of Pulses Research, Kanpur-208 024

Jaiswal, P.C. (2006) Soil, Water and plant Analysis, Manual Practical.

Jackson, M. L., (1958) Soil chemical analysis, Second edition Indian Reprint, prentice hall of India, New Delhi. Pp498.

Karpechenko, G. D (1925) Chromosomes of Phaseolinae. Bull. Appl. Bot., 14: 143-148.

Katyayan A. (2012) Manures, fertilizers and biofertilizers, Fundamentals of agriculture. Kushal publications and distributors Varanasi.Vol.-1; p 231-251

MeenaS.,Swaroop N. and Dawson J. (2016) Effect of integrated nutrient management on growth and yield of green gram (Vigna radiata L.) Agric. Sci. Digest., 36 (1) 2016: 63-65

Murugan, R., Apillai, S.C., Niemsdorff, P.F. and Nanjappan, K. (2011) Effects of combined application of biofertilizers with neem cake on soil fertility, grain yield and protein content of black gram (Vigna mungo (L.) Hepper). World journal of Agricultural sciences 7 (5): 583-590.
Muthuaval, P.C., Udayasooriyan, R., Natesan, P.P. and Ramaswami (1992). Introduction to soil Analysis, Tamilnadu Agriculture University, Coimbatore-641002.

Olsen, S. R., Cole, C. V., Watanhe, F. S. and Dean, L. A. (1954) Estimation of available Phosphorus in soils by extraction with sodium bicarbonate U. S. Deptt. Agr. Circ. 939.

Prasad, K. (2009) a text book field production, ICAR publications, New Delhi, pp. 257-258.

Rajveer, David A. A. and Khadda B. S. (2016) assessment of integrated nutrient on crop growth parameters and yield of green gram (Vigna radiata L.). Society for Scientific Development in Agriculture and Technology.6277-6279.

Sahil, S. and P. K. Bandopadhya (2007) Retaining seed vigour and viability of mungbean by drought dressing treatments. Journal of Food Legumes. 20: 173-175.

Subbaiah, B. V. and Asija, C. L. (1956) A rapid procedure for the estimation of available nitrogen in soil.Current Sciences; 25:259260.

Takase, M., Owusu, L. K. and Sekyere, J. D. (2011) the effects of four sources of irrigation water on soil chemical and physical properties. Asian Journal of Plant Sciences; 10: 1, pp 92-96.18.

Toth, S. J. and Prince, A. L. (1949) Estimation of cation exchange capacity and exchangeable $\mathrm{Ca}, \mathrm{K}$ and $\mathrm{Na}$ content of soil by flame photometer technique. Soil Sci., 67: 439-445.

Walkley, A. and Black, I. A. (1947) Critical examination of rapid method for determining organic carbon in soils, effect of variance in digestion conditions and of inorganic soil constituents. Soil sci pp.632:251.

Wilcox L.V. (1950) Electrical conductivity, Amer. Water works Assoc. J. 42: pp. 775776.

\section{How to cite this article:}

Rajesh and Arun Alfred David. 2017. Response of Neem Cake Rhizobium and Inorganic Fertilizer on Soil Health Growth and Yield of Green gram (Vigna radiata L.) var. Samrat. Int.J.Curr.Microbiol.App.Sci. 6(7): 815-821. doi: https://doi.org/10.20546/ijcmas.2017.607.100 